\title{
食道粘膜下腫瘍の内視鏡下ポリペクトミー症例の検討
}

\author{
小野澤君夫，鍋谷 欣市，本島 悌司 \\ 加来 朝王, 川口 敏樹, 小口 晋平 \\ 新井 裕二
}

\section{Endoscopical Polypectomy for Esophageal Submucosal Tumors}

Kimio Onozawa, M.D., Kin-ichi Nabeya, M.D., Teiji Motojima, M.D., Cho-o Kaku, M.D., Toshiki Kawaguchi, M.D., Shimpei Oguchi, M.D., and Yuji Arai, M.D.

Second Department of Surgery, Kyorin University School of Medicine, Tokyo

For the polypoid and semi-polypoid type of the esophageal submucosal tumors under $20 \mathrm{~mm}$ in diameter, the endoscopical polypectomy is frequently and safely performed.

According to Japanese reports, esophageal leiomyosarcoma of small size tends to be diagnosed as benign. Consequently, for the differential diagnosis for leiomyosarcoma, it is significant to perform endoscopical polypectomy for esophageal submucosal tumors.

It is useful to classify the esophageal hemangioma into three groups for diagnosis and endoscopical treatment. The bluish sessile type is classified as group I ; the bluish semipolypoid type is classified as group II ; and normal colored type is classified as group III. It is quite easy to make endoscopical diagnosis of hemangioma in group I and II, but difficult in group III. For the tumors under $20 \mathrm{~mm}$ in group II and III, the endoscopical polypectomy is safely performed. In group I, the endoscopical injection sclero therapy is easily performed.

\section{Key words : 食道粘膜下腫場, 内視鏡下ポリペクトミー, 食道平滑筋腫, 食道平滑筋肉腫, 食道血管腫}

\section{はじめに}

食道良性腫瘍に対する治療法の一つとして, 近年内視鏡下ポリペクトミーの報告が多数みら れる。われわれは，内視鏡下ポリペクトミーを 施行した 3 治験例を経験したので症例を提示 し, あわせて食道良性腫瘍の治療法に関して, 内視鏡下ポリペクトミーの適応と問題点を中心

杏林大学医学部第 2 外科

別刷請求： $=181$ 東京都三鷹市新川6-20-2 杏林大学医学部第 2 外科 小野澤君夫

投稿受付：1987年12月 9 日
に若干の検討を加えて報告する。

\section{症 例}

われわれが経験した食道良性腫瘍は18例で, 治療法は食道切開腫瘤切除術 1 例 - 腫瘤核出術 4 例・内視鏡下ポリペクトミー 3 例・内視鏡下 硬化剂注入法 1 例であり, 9 例は経過観察を行 った。内視鏡下ポリペクトミーを行った 3 例を 提示する。

症例 175 歳, 女性。6 6 月前から時々嬩下 時つかえ感があり来院した。内視鏡検査では切 歯列 $20 \mathrm{~cm}$ 後壁に, 小指頭大の腫瘤があり,くび れを有し表面は正常粘膜でおおわれていた（図 


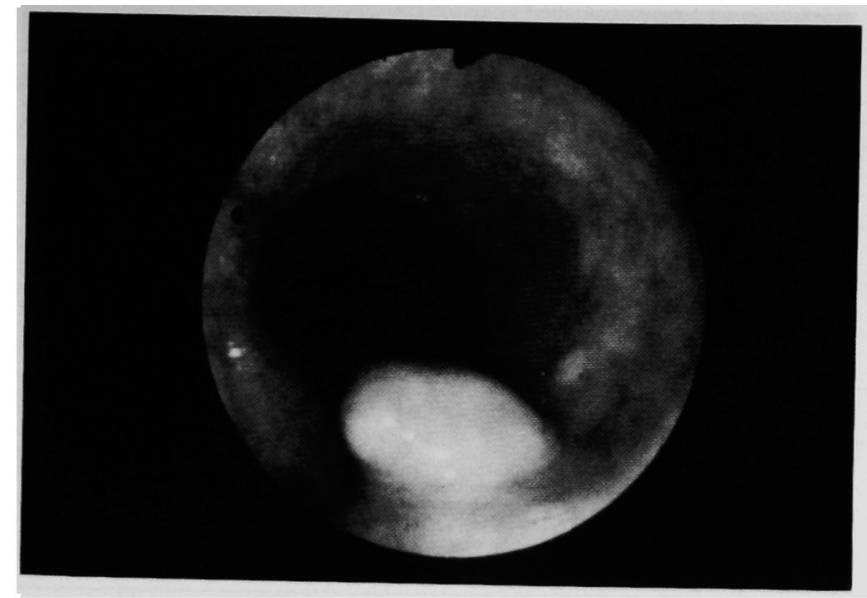

図 1 症例 1 内視鏡所見

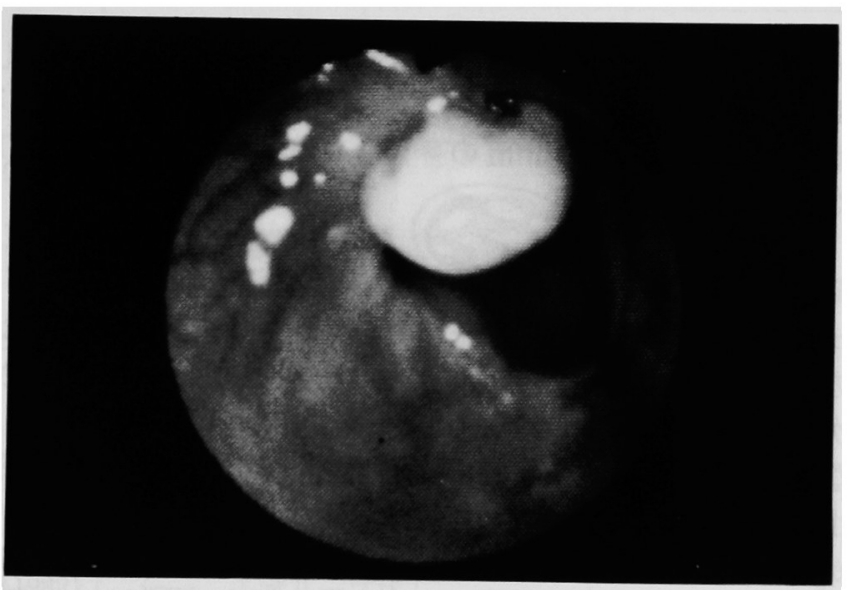

図 2 症例 2 内視鏡所見

1)。食道良性粘膜下腫瘍の診断で内視鏡下ポリ ペクトミーを行い, 順調に経過した。剔出標本 は $13 \times 12 \times 7 \mathrm{~mm}$ の平滑筋腫であった。

症例 282 歳, 男性。20年前から軽度の嬩下 障害があったが，1 か月前に食物がつかえたこ とで近医を訪れ, X線検査で食道下部の異常陰 影を指摘され当科を紹介された。内視鏡検査で は切歯列 $43 \mathrm{~cm}$ 左前壁に, 示指頭大の腫瘤があ り，くびれを有し表面は正常粘膜におおわれて いた(図 2 )。食道良性粘膜下腫湯の診断で, 内 視鏡下ポリペクトミーを行い順調に経過した。 剔出標本は $18 \times 11 \times 8 \mathrm{~mm}$ で, 蛇行・拡張した 毛細血管の新生と一部に内皮細胞の増生・腫大 がみられ，毛細血管腫と診断した（図 3 )。

症例 360 歳, 男性。食道症状はなく, 胃潰

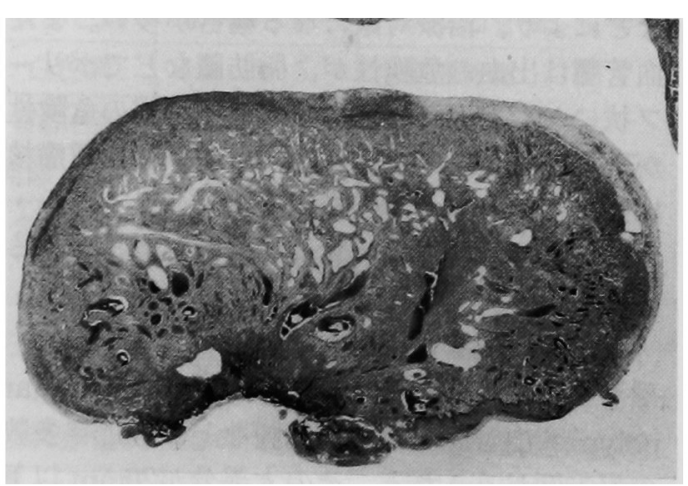

図3 症例 2 組織所見

瘍に対する上部消化管内視鏡検査の際に，切歯 列 $37 \mathrm{~cm}$ 右後壁に半米粒大の低い隆起を発見し た。黄白色調で表面はほほ粘膜におおわれ，一 


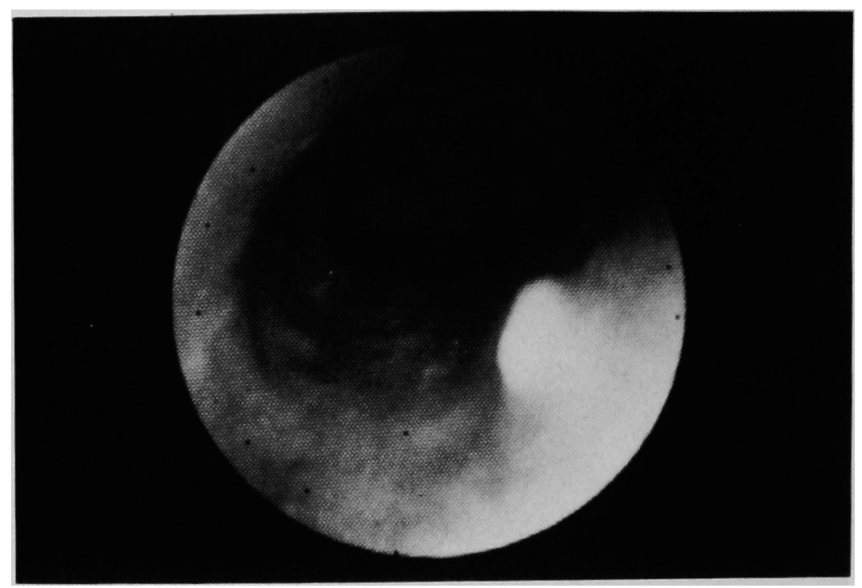

図4 症例 3 内視鏡所見

部に浅い粘膜欠損があった(図 4)。食道顆粒細 胞腫の疑診で内視鏡下ポリペクトミーを行い, 順調に経過した。剔出標本は $5 \times 5 \times 3 \mathrm{~mm}$ の 顆粒細胞腫であった。

\section{考 察}

食道良性腫瘍は比較的少ない疾患であり，そ の中で頻度が高いのは平滑筋腫で文献上 60 ～80 \%を占めている。次いで, ポリープ・囊腫・血 管腫・顆粒細胞腫などである。

食道良性腫瘍の小さいものは無症状のため経 過観察されることが多いが，大きくなると嚥下 障碍が現われること, 食道癌が発生する危険が 高い1)と, 平滑筋肉腫との鑑別が難しいこと などにより，治療対象になる場合が多い。また 血管腫は出血の危険性が, 脂肪腫などでポリー プ状になるものは吐逆による気道閉塞の危険性 が2), 治療の適応に加えられる。治療法は腫瘤核 出術が標準とされ, 内視鏡下ポリペクトミー・ 食道切開腫瘤切除術・食道切除術が選択される 場合もある。

食道良性腫瘍の内視鏡下ポリペクトミーは, 平滑筋腫・線維血管性ポリープ（fibrovascular polyp）・血管腫・顆粒細胞腫などに, 近年多数 の報告例がみられる。その大部分が $20 \mathrm{~mm}$ 以下 の亜有茎性のものであるが, $20 \mathrm{~mm}$ 以上の大き いものや広基性のものにも施行されている。報 告例のほとんどは経過良好であるが, 中には食 道穿孔例もあり, その危険性が示唆される。わ
れわれは前述の 3 例を経験しているが，いずれ も長径 $20 \mathrm{~mm}$ 以下であり, $20 \mathrm{~mm}$ 以上の大きい ものや広基性のものには, 腫瘤核出術を選択し ている。

X線や内視鏡による食道良性腫瘍と食道悪性 腫瘍との鑑別診断については, 食道悪性腫瘍の うち癌・癌肉腫・悪性黒色腫は容易である。平 滑筋肉腫の大きいものは潰瘍を形成するので鑑 別は比較的容易であるが，小さく正常粘膜にお おわれるものは鑑別診断が難しい。本邦45例の 食道平滑筋肉腫報告例から長径 $50 \mathrm{~mm}$ 以下を 集めると 6 例 ${ }^{3) \sim 8)}$ になる(表 1 )。このうち 4 例 は良性腫瘍と診断され, 腫瘤核出術が施行され ている。いずれも手術所見や剔出標本肉眼所見 でも良性と診断され, 組織検査ではじめて平滑 筋肉腫と診断されて, そのうち 2 例が局所再発 をおこして死亡している。

このことから, 食道良性粘膜下腫瘍と診断し た長径 $20 \mathrm{~mm}$ 前後の腫瘤は, 内視鏡下ポリペク トミーで完全生検すべきだという積極的な考え 方がでてくる。しかし，食道筋腫は壁外方向に 発育する頻度が高く, 食道は漿膜がないので, 穿孔や不完全切除の危険性も高い。したがって, 長径 $20 \mathrm{~mm}$ 以上のものと広基性のものは, 超音 波内視鏡や CTにより大きさ・形状・壁外性発 育程度を診断して, 腫瘤核出術か内視鏡ポリペ クトミーかの適応を決定するのが良いと考えて いる。

食道血管腫の治療法は, 従来大きなものや出 
表 1 食道平滑筋肉腫報告例（長径 $5 \mathrm{~cm}$ 以下）

\begin{tabular}{|c|c|c|c|c|c|}
\hline No. & 報 告 者 & 臨床診断 & 手術術式 & 大きさ $(\mathrm{mm})$ & 予 \\
\hline 1 & 飯塚 (1970) & 粘膜下腫瘍 & 腫瘤核出術 & $40 \times 30 \times 30$ & 12 年 10 月再発死 \\
\hline 2 & 山内 (1972) & 筇 腫 & 腫瘤核出術 & $40 \times 17$ & 再発死 \\
\hline $3^{*}$ & 斉藤 (1976) & 癌 & 食道要全剔術 & $25 \times 16 \times 27$ & 1 年 7 月生 \\
\hline 4 & 藤田 (1978) & 肉 腫 & 食道亚 & $50>$ & 2 年 1 月生 \\
\hline 5 & 中村 (1978) & 粘膜下腫瘍 & 腫瘤核出術 & $25 \times 25$ & 6 年 \\
\hline 6 & 吉田 (1978) & 粘膜下腫瘍 & 腫瘤核出術 & $35 \times 28 \times 20$ & 2 年 1 月生 \\
\hline
\end{tabular}

*術前照射3000 rad 施行し，腫瘤の縮小をみた。

表 2 食道血管腫の臨床分類

\begin{tabular}{c|c|c|c}
\hline & 1 群 & 2 群 & 3 群 \\
\hline 形 態 & 山田 I 〜II型 & 山田III型 & 山田 II III型 \\
\hline 色 調 & 青 色 調 & 青 色 調 & 変化なし \\
\hline 断面図 & & & \\
& & &
\end{tabular}

表 3 食道血管腫内視鏡下ポリペクトミー報告例

\begin{tabular}{|c|c|c|c|c|c|c|}
\hline . & 報 告 書 & 手齢 性 & 形 態 & 粘膜色調 & 大きさ & 租 \\
\hline 1 & 川原 (1982) & 30歳 女 & 有茎性 & 発赤・びらん & $8 \times$ & 毛細 \\
\hline 2 & 幕内 & 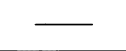 & ポリ & - & & 管腫 \\
\hline 3 & 小口( & 82歳 男 & 山田III型 & 白色調 & $18 \times$ & 毛細 \\
\hline 4 & 東野( & 57歳 男 & 山田III型 & 青赤色調 & $24 \times 23 \times 18$ & 海綿状 \\
\hline 5 & 倉下 (1984) & 41歳 男 & 垔有茎性 & 白色調 & $6 \times$ & 毛細 \\
\hline 6 & 工藤 & 76歳 & 茎性 & 青赤色調 & $22>$ & 毛䊽 \\
\hline 7 & 佐藤 (1985) & 50歳 男 & 山田III型 & 発赤・白苔 & $5 \times 3$ & 毛細血管腫 \\
\hline 8 & 新井( & 56歳 女 & 有 & 青示 & $22 \times 13 \times 7$ & 海綿状血管 \\
\hline
\end{tabular}

血の危険が考えられるものに対して，腫瘤核出 術や食道切除術の報告9) 11)がみられるが，近年 内視鏡下ポリペクトミーの報告12) 18)も多数み られ，内視鏡下硬化剂注入 ${ }^{199}$ も行われている。し かし，血管腫の内視鏡下ポリペクトミーに対し ては, 出血の危険性から批判的な意見も多い。

そこでわれわれは食道血管腫本邦報告43例の 診断と治療を検討し, その形態と色調の違いか
ら 3 群 ${ }^{14)} に$ 分けてみた（表 2 )。1 群は山田 I 〜 II 型20)で青色調のもの，2 群は山田III型で青 色調赤色調のもので，いずれも内視鏡的に血管 腫との診断は容易である。3 群は山田III型で粘 膜色調に変化がないか白色調のもので, 内視鏡 的には粘膜下腫瘍としか診断しえない。その違 いは, 1 群 2 群は粘膜直下に比較的血液容量が 多い血管腔が存在するが， 3 群は粘膜直下には 
線維性組織が多く深部に血管腔が存在するため である。1群は小さいことが多い。われわれが 呈示した症例 2 は 3 群に相当する。

内視鏡下ポリペクトミーが行われた 8 例の形 態はすべて山田III〜IV型で，表面粘膜色調は青 赤色調 3 例 - 発赤 2 例 - 白色調 2 例 - 不明 1 例 であり,われわれの分類の 2 群と 3 群に相当す る。長径は最大 $24 \mathrm{~mm}$ 平均 $15 \mathrm{~mm}$ であり, 組織 診断は毛細血管腫 5 例海綿状血管腫 3 例である (表 3 )。なお, ポリペクトミー時の出血を考慮 して, Nd-YAG レーザー焼灼15)や無水エタノー ル注入 ${ }^{17)}$ の夫もみられるが，われわれの症例 を含め後出血はないようである。したがって, 2 群 3 群では血管腫の存在部位は粘膜下層と考 えられるので, ポリペクトミーによる出血の危 険性は少ないと思われる。さらに安全を期する には超音波内視鏡で存在部位の確認を行えばよ い。1 群の血管腫に対しては内視鏡下硬化剂注 入法か手術治療が選択されるべきであろう。

\section{ま と め}

1. 食道良性腫暘内視鏡下ポリペクトミーの 3 治験例を呈示した。

2. 食道良性腫瘍に対する内視鏡下ポリペクト ミーは, 長径 $20 \mathrm{~mm}$ 以下の有茎性亜有茎性の ものに, 安全に行われている。

3. 食道平滑筋肉腫の小さいものは良性粘膜下 腫瘍と診断される率が高いので，良性粘膜下 腫瘍と診断した場合は，適応を選んで内視鏡 下ポリペクトミーを施行すべきである。

4. 食道血管腫は 3 群に分けるのが, 診断なら びに治療上有意義である。青色調赤色調のも のは診断容易であるが, 白色調ないし正常色 調のものは診断が難しい。亜有茎性のものは 内視鏡下ポリペクトミーが，広基性のものは 内視鏡下硬化剂注入法が治療法の一つとな る。

この論文の要旨は, 第39回日本気管食道科学会総 会で発表したものである。

\section{文献}

1) 藤崎真人, 安藤暢敏, 三吉 博・他：食道平滑 筋腫上に認められた早期食道癌の 1 例。日消外 会誌, $17: 641-644,1984$.
2 ) 小口晋平, 鍋谷欣市, 小野澤君夫・他：口腔外 に吐出した食道脂肪腫の 1 治験例. 日消外会誌, $18: 118-121,1985$.

3 ）飯塚紀文, 平田克治, 三富利夫・他：食道平滑 筋肉腫の切除 5 年生存例. 日消誌, $67: 270-275$, 1970.

4 ）山内秀夫, 杉田輝地, 野田辰男 - 他 : 若年者に 発生した頸部食道平滑筋肉腫. 外科診療, 14 : 599-602, 1972.

5 ) 斉藤寿一, 曾我 淳, 小林清男・他：食道平滑 筋肉腫の一治験例. 癌の臨床, $22: 339-342$, 1976 .

6 ）藤田秀春, 草島義徳, 宮崎逸夫 - 他 : 食道平滑 筋肉腫の 1 治験例. 外科治療, $38: 241-246$, 1978.

7 ) 中村 讓, 川原克信, 中尾 丞-他：食道平滑 筋腫瘍の検討. 外科, $40: 969-976,1978$.

8 ) 吉田 沖, 浜口伸正, 湯浅亮一・他: 食道平滑 筋肉腫の手術経験。医療, $34: 65-68,1980$.

9 ）曽我基行, 大沢幹夫, 牛田 昇 -他: 食道血管 腫の 1 治験例。臨床外科, $29: 419-422 ， 1974$.

10）綾部公懿, 中村 譲, 南 寛行 - 他：食道血管 腫の 1 例. 日胸外会誌，28：1882-1887，1980。

11）星加和徳, 長崎貞臣, 宮島宣夫 - 他：食道血管 腫の 1 例. Gastroenterol. Endosc., $26: 1309-$ 1313, 1984 .

12）川原文次，佐竹国重，野口忠興・他：内視鏡的 ポリペクトミーを施行し得た有茎性食道血管腫 の 1 例. Gastroenterol. Endosc., 25:1129, 1983.

13）幕内博康, 杉原 隆, 中崎久雄 - 他：内視鏡的 食道ポリペクトミーの検討. Gastroenterol. Endosc., $25: 958,1983$.

14）小口晋平，鍋谷欣市，小野澤君夫・他：内視鏡 的ポリペクトミーを施行した食道血管腫の 1 例. Gastroenterol. Endosc., 29:96-100, 1987.

15）吉岡幸男，酒井克治，浜中良郎・他：食道血管 腫の 3 例, 消化器外科, $8: 370-376,1985$.

16）倉下 隆, 林 隆一, 越川裕二・他：内視鏡的 ポリペクトミーを施行し得た食道血管腫の 1 例. Gastroenterol. Endosc., $27: 1882-1883$, 1985 .

17）工藤正俊, 平佐昌弘, 高鈋 博 - 他：内視鏡的 ポリペクトミーにて切除し得た食道血管腫の 1 例. Gastroenterol. Endosc., $28: 318-324,1986$.

18）佐藤勝久, 浅木 茂, 小関弥平：内視鏡的ポリ ペクトミーを施行した食道血管腫の 1 例. Gastroenterol. Endosc., 29:370, 1987.

19）長崎雄二，小林輝久，藤井康広・他：食道血管 腫と思われる病変に対する Aethoxysklerol 注 入の 1 治験例. 消化器内視鏡の進歩. $24: 206-$ 209, 1984

20）山田達哉, 福富久之：胃隆起性病変. 胃と腸, $1: 145-150,1966$ 